\title{
Balanced scorecard for evaluating the performance of supply chains: A bibliometric study
}

\author{
Thales Botelho de Sousa*, Isotilia Costa Melo*, Pedro Henrique de Oliveira*, Caio Marcelo Lourenço*, \\ Fábio Müller Guerrini* and Kleber Francisco Esposto* \\ *Industrial Engineering Department, São Carlos School of Engineering, University of São Paulo, São Carlos, São Paulo, Brazil \\ Corresponding Author: thaleseafsal@yahoo.com.br
}

\begin{abstract}
As supply chain management involves several criteria, its performance evaluation is a challenge for industrial managers. Researchers have proposed several approaches for such evaluations, among them are Balanced Scorecard (BSC) highlights. Academic papers on BSC applications for evaluating supply chain performance have been expressively increased in recent years. Considering that examining published papers on a topic is a way of monitoring the emergence of a new field, this study aims to explore, through Bibliometrics, papers published in indexed journals (SCOPUS and Web of Science databases). This paper weaves an overview of academic production and study trends on BSC for performance evaluation of supply chains. Findings help researchers and managers understand the stateof-the-art, to identify gaps and to identify future trends. The results also showed the maturation of studies over the years. The predominance of publications in journals with impact factor (Thomson Reuters) also has been noticed. The development of the theme in emerging countries can be useful for increasing the competitiveness of their companies. In summary, this study is helpful for influencing future studies and publications of researchers interested in performance evaluation of supply chains based on BSC and may orient new researchers so that they directly know which journals to consult and which technical procedures to explore.
\end{abstract}

Keywords: Balanced Scorecard; Supply Chain Management; Performance Evaluation; Bibliometry; Emerging Countries.

\section{INTRODUCTION}

Globalization, growing competition, has contributed to highlighting the importance of business management, principally Supply Chain Management (SCM). Supply chains are a set of industrial installations, supplies, clients, goods, and methods of monitoring inventory, purchasing, and distribution that link suppliers and customers (Xu et al., 2009). An efficient supply chain provides essential benefits for a world of global competition, such as reduced costs, growth in sales and market share, and sustainable relationships with customers and suppliers (Shafiee et al., 2014).

Performance evaluation of supply chains is considered an important element of companies' accomplishment, as well as one of the broader strategic decision issues (Dath et al., 2010). Decision-makers and manager are expected to formulate effective SCM and share information with the whole chain so that they can mitigate the bullwhip effect (Shiau et al., 2015).

Performance evaluation of supply chains aims to obtain information on activities and to identify opportunities for improvement. Information is crucial when activities are not suitable to the defined targets, in order to reorient their movement. Both information and opportunity identification are critical when performance is below the goal and it needs attention for not impacting upon financial results.

The integration of the performance of all its members increases the efficiency of a supply chain (Shafiee et al., 2014). Consequently, the performance evaluation of supply chains is a complicated task, because this evaluation involves several actors who are seeking to obtain better logistical and strategic goals (Estampe et al., 2013). 
Several approaches have been developed to evaluate the performance of supply chains, and some of the most prominent ones are Balanced Scorecard (BSC), criteria for measurement system design, Economic Value Added (EVA), fuzzy-set approach, measurement system of supply chains, performance measurement matrix, performance measurement questionnaire, process-based measurement, and SCOR (Brun et al., 2009; Piotrowicz and Cuthbertson, 2015; Shafiee et al., 2014).

Park et al. (2005) state that some studies in SCM just propose a common framework for its metrics and there is need for a more integrated perspective between financial and non-financial aspects. The BSC is one of the most simple and comprehensive performance evaluation tools. It embraces simultaneously internal and external business measures, financial and non-financial factors, and long- and short-term plans of action (Shafiee et al., 2014). According to Bronzo et al. (2013), among the contemporary performance evaluation systems, BSC is the methodology that has gained more acceptance in academic communities and business models. In recent years, companies are stimulated to adopt BSCs for measuring supply chain performance (Chang et al., 2013).

BSC is a cause and effect method used to reveal in which parameters an organisation is a leader and, simultaneously, in which parameters it presents a low performance (Eskafi et al., 2015). It is a tool that reflects the strategy and the mission of an organisation into a set of unbiased and measurable indicators. BSC is composed of four distinct perspectives: customers, financial, internal business processes, and learning and growth (Kaplan and Norton, 1996, Tsang et al. 1999). For Wu and Chang (2012), BSC is appropriate to overcome the performance evaluation-related issues in supply chains, and its acceptance as a method for implementing business strategies has significantly increased (Zimmermann and Seuring, 2009).

BSC evaluates performance considering six dimensions of integration: (1) customer, (2) internal process, (3) measurement, (4) relationship, (5) supplier services with material supply, and (6) technology with planning (Chang, 2009). By linking these dimensions, BSC supports managers to perceive and understand the associations and tradeoffs among optional performance degrees, thus leading to enhanced decisions (Rajesh et al., 2012).

Through a bibliographical search in SCOPUS and Web of Science databases (detailed information under section 2 Method), we found 100 published studies on performance evaluation of supply chains based on BSC. The first paper about the theme was published in 2002, then the theme has been consistently increasing in recent years. Therefore, it is important to have an overview of the academic production on the theme.

The bibliometric studies can collaborate in the task of systematizing the research carried out in a certain field of knowledge and addressing problems to be investigated in future research. In this way, the bibliometric research provides the basis for the gradual development of scientific knowledge. Several academic disciplines in the area of management have analysed their researches under the optical of bibliometric characteristics (Hsieh and Chang, 2009) because analysis through bibliometric tools is usually powerful for detecting emerging and established topical areas (Fahimnia et al., 2015). Shiau et al. (2015) state that performance measurement in SCM is a relevant research topic that needs to be better addressed in the literature. Hence, the purpose of this research is to examine the literature related to performance evaluation of supply chains based on BSC.

It is possible to assess the literature by journals, citations, countries, and technical procedures, using bibliometric methods. This study is helpful for influencing future studies and publications of researchers interested in performance evaluation of supply chains based on BSC and aims to orient researchers who are new in the research field so that they know which journals to consult and which technical procedures to explore when studying this theme.

This study is divided into 4 sections. Section 2 provides detailed information about the adopted methodology. The results, according to the analysed criteria (journal, authors' affiliation country, and applied technical procedures), are under section 3. Conclusion, limitations, and recommendations for future researches are under section 4. 


\section{METHODOLOGY}

The used method aims to obtain results capable of addressing the academic researchers progress on the use of Balanced Scorecard for the performance evaluation of supply chains. Considering that it is complicated to have an explicit distinction between publications with high-quality level and those that are not and that not all publications have the same value to scientists, this work restricted its bibliographical sources to SCOPUS and Web of Science databases. They were selected due to their broad utilization and impact on the international academic community (RomoFernández et al., 2011). The bibliographic search ended in January 2017, and following the directions recommended by Carnevalli and Miguel (2008) and Ngai et al. (2008), we selected only studies published in journals, as they are considered as studies of the best scientific level. In the searches, following the directions recommended by Charvet et al. (2008), we used the keywords "supply chain*" and "Balanced Scorecard" in the title, abstract, and author-supplied keywords to collect worthwhile information. At total, 100 studies truly related to the proposed theme were found. For the analyses presented in this manuscript, only papers published until December 31, 2016, were included.

Bibliometric technics are indispensable tools for measuring scientific progress, as they simultaneously summarize the dominant trends and points knowledge gaps (Blank et al., 2013). Bibliometrics may be used as a base for qualitative evaluation, but it is worth remembering that it is a quantitative tool by nature (Du et al., 2015).

The application of bibliometric techniques permits carrying out different analysis, e.g., main authors (Willett, 2007), emerging topics and contemporary developments in a research field (Shafique, 2013), and the influence of researchers (Ferreira, 2011). Baumgartner and Pieters (2003) assess the importance of different journals in bibliometric studies. Other authors focus on the affiliation of authors (Podsakoff et al., 2008) or on the intellectual framework of an area (Ramos-Rodriguez and Ruiz-Navarro, 2004). According to Bornmann and Marx (2015), considering the methodology of an approach has its own advantages and disadvantages, which manifest for or against its use, a researcher using bibliometric indicators in a study must know which approach to adopt. In this research, the bibliometrics was used to evaluate the chronological growth of scientific production, main journals diffusing papers, and distribution of the papers among countries, in order to check whether studies are predominant in emerging or advanced economies.

\section{BIBLIOMETRIC ANALYSIS}

The first paper that published BSC for evaluating the supply chains performance appeared in SCOPUS and Web of Science databases in 2002. Table 1 lists the annual quantity of studies and in which journal the papers were published. Table 1 presents that, with some variations, there was a growth over the years of studies that address the use of BSC for evaluating the performance of supply chains, considering that in 2002 only 1 paper was published and in 2012, the highest number of papers published increased to 15 .

The 100 papers on the theme published in SCOPUS and Web of Science databases were presented in 72 journals, pointing that the research field does not yet have established channels for presenting its works, a typical demonstration of it being in a 'growing' state. Consolidated fields tend to have their papers published in a smaller quantity of specialised journals, ensuring less 'dispersion' of knowledge and more assertive search methods for a particular theme (von Krogh et al., 2012).

Looking at Table 1, $82 \%$ of journals published just one paper on the theme; $8.3 \%$ published two papers; and $5.55 \%$ published three papers. Only three journals published more than three papers, i.e., Production Planning and Control (7 papers; 7\% of the total), Benchmarking (5 papers; 5\%), and International Journal of Production Research (5 papers; $5 \%$ ).

Looking for trends over time, Figure 1 clearly shows that the quantity of publications in journals with and without an IF has varied clearly from 2004 onwards. Whereas the participation of journals without an IF increased, the number of papers published in journals with an IF has increased simultaneously. Considering the relative novelty of the theme, the increase of publications in journals with an IF might be a sign of increasing academic attractiveness, as such occurrence originates higher-quality researches, and states topic is 'publishable' in the perception of the editors-inchief, editorial board, and reviewers. 


\begin{tabular}{|c|c|c|c|c|c|c|c|c|c|c|c|c|c|c|c|}
\hline \multicolumn{2}{|c|}{ 矛 } & $r$ & in & $n$ & $m$ & $m$ & $m$ & $m$ & $N$ & $\sim$ & $N$ & $N$ & $\sim$ & $\sim$ & 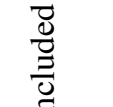 \\
\hline \multirow{17}{*}{ 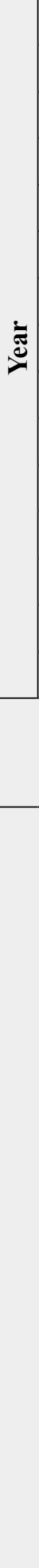 } & 2016 & & - & - & & & & - & & & & $N$ & & & $\overrightarrow{0}$ \\
\hline & 2015 & & & - & $N$ & - & - & $N$ & & & & & - & & $\underset{乛}{ే}$ \\
\hline & 2014 & $n$ & - & & & - & & & & & & & & &. \\
\hline & 2013 & & & & - & & & & & - & & & & & ä \\
\hline & 2012 & - & & - & & & & & - & & $\sim$ & & & & $\stackrel{\oplus}{9}$ \\
\hline & 2011 & & & & & & - & & & & & & - & & 4 \\
\hline & 2010 & & - & - & & - & & & & & & & & & E \\
\hline & 2009 & $N$ & $\sim$ & & & & - & & & & & & & & శ్ \\
\hline & 2008 & & & & & & & & & & & & & & 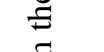 \\
\hline & 2007 & - & & & & & & & - & & & & & & \\
\hline & 2006 & & & & & & & & & & & & & $\sim$ & $\stackrel{\Xi}{\Xi}$ \\
\hline & 2005 & & & & & & & & & - & & & & & \\
\hline & 2004 & & & & & & & & & & & & & & $\begin{array}{l}\mathscr{D} \\
\stackrel{5}{0}\end{array}$ \\
\hline & 2003 & & & & & & & & & & & & & & \\
\hline & 2002 & & & - & & & & & & & & & & & \\
\hline & 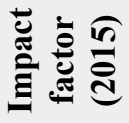 & ñ & ' & $\stackrel{n}{\sigma}$ & ' & $\stackrel{\infty}{\stackrel{\infty}{ஸ}}$ & $\stackrel{\vartheta}{m}$ & $\stackrel{m}{+}$ & $\begin{array}{l}0 \\
\infty \\
0 \\
i\end{array}$ & \begin{tabular}{l}
$n$ \\
$\infty$ \\
0 \\
\hdashline \\
-1
\end{tabular} & $\begin{array}{l}\text { J } \\
\text { i } \\
\text { i }\end{array}$ & $\begin{array}{l}\hat{\sigma} \\
\hat{\sigma}\end{array}$ & ' & ' & 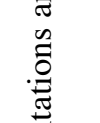 \\
\hline & & 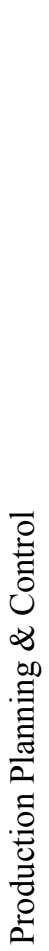 & 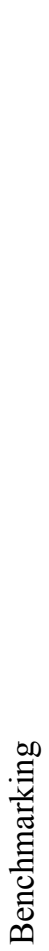 & 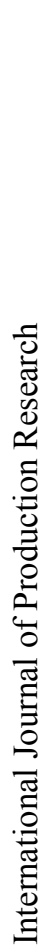 & 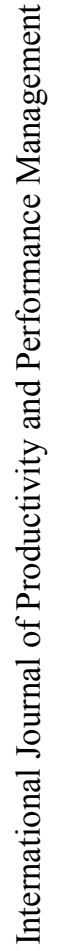 & 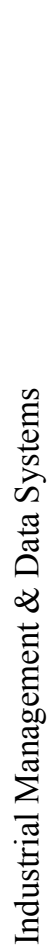 & 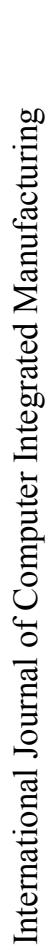 & 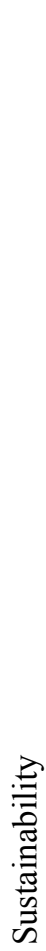 & 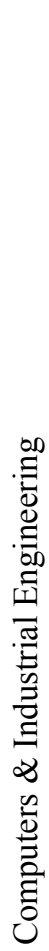 & 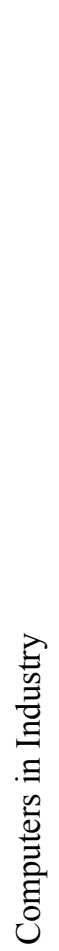 & 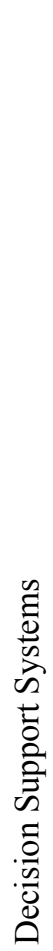 & 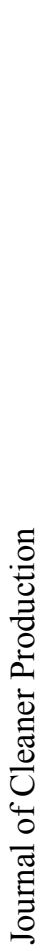 & 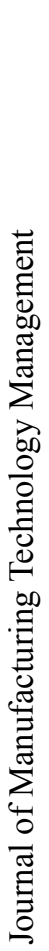 & 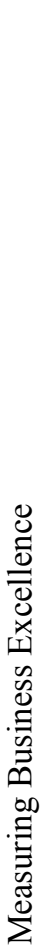 & 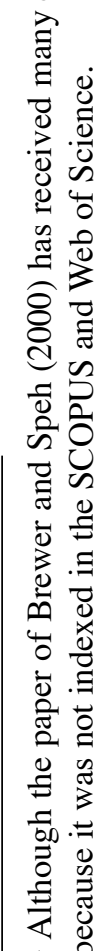 \\
\hline
\end{tabular}




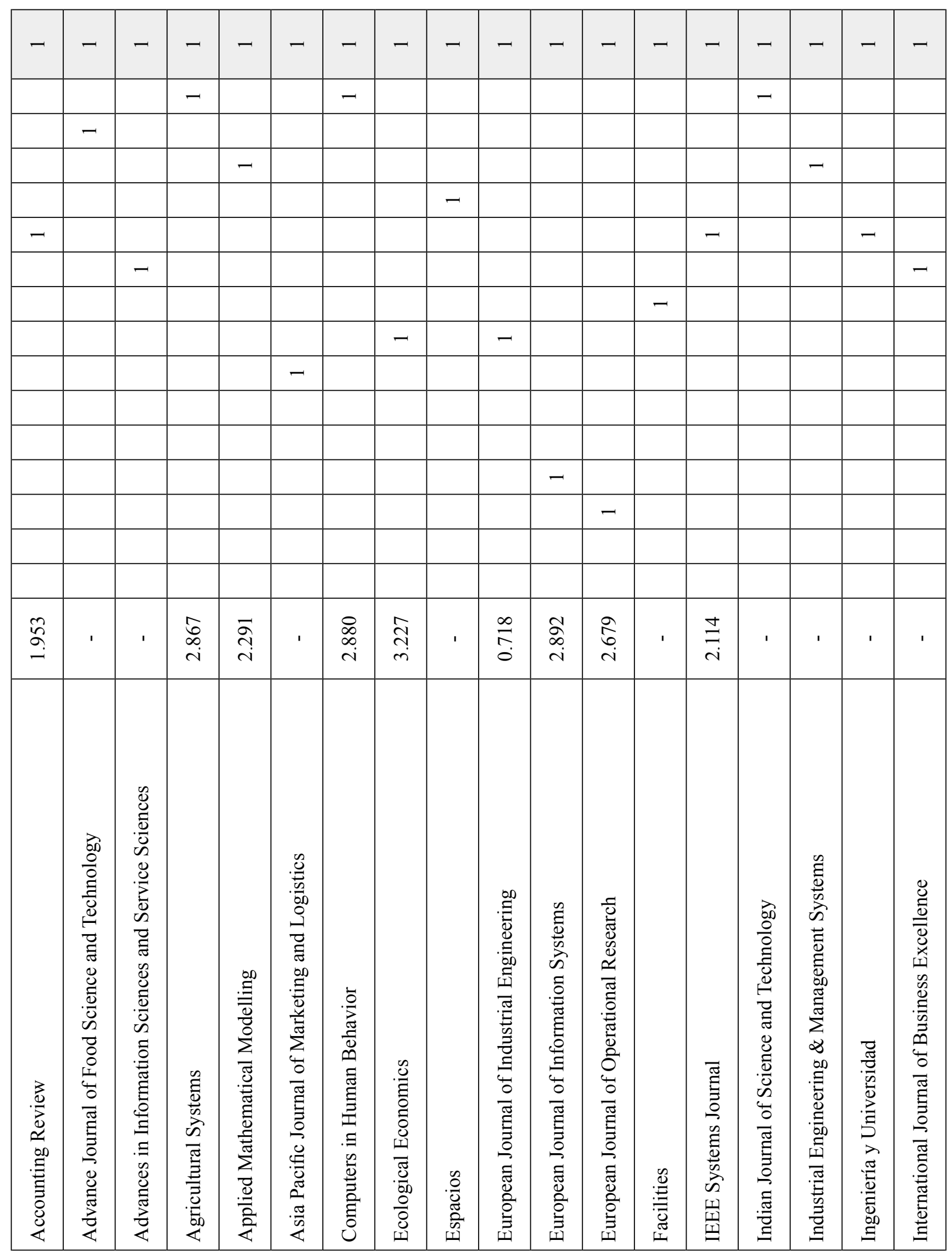




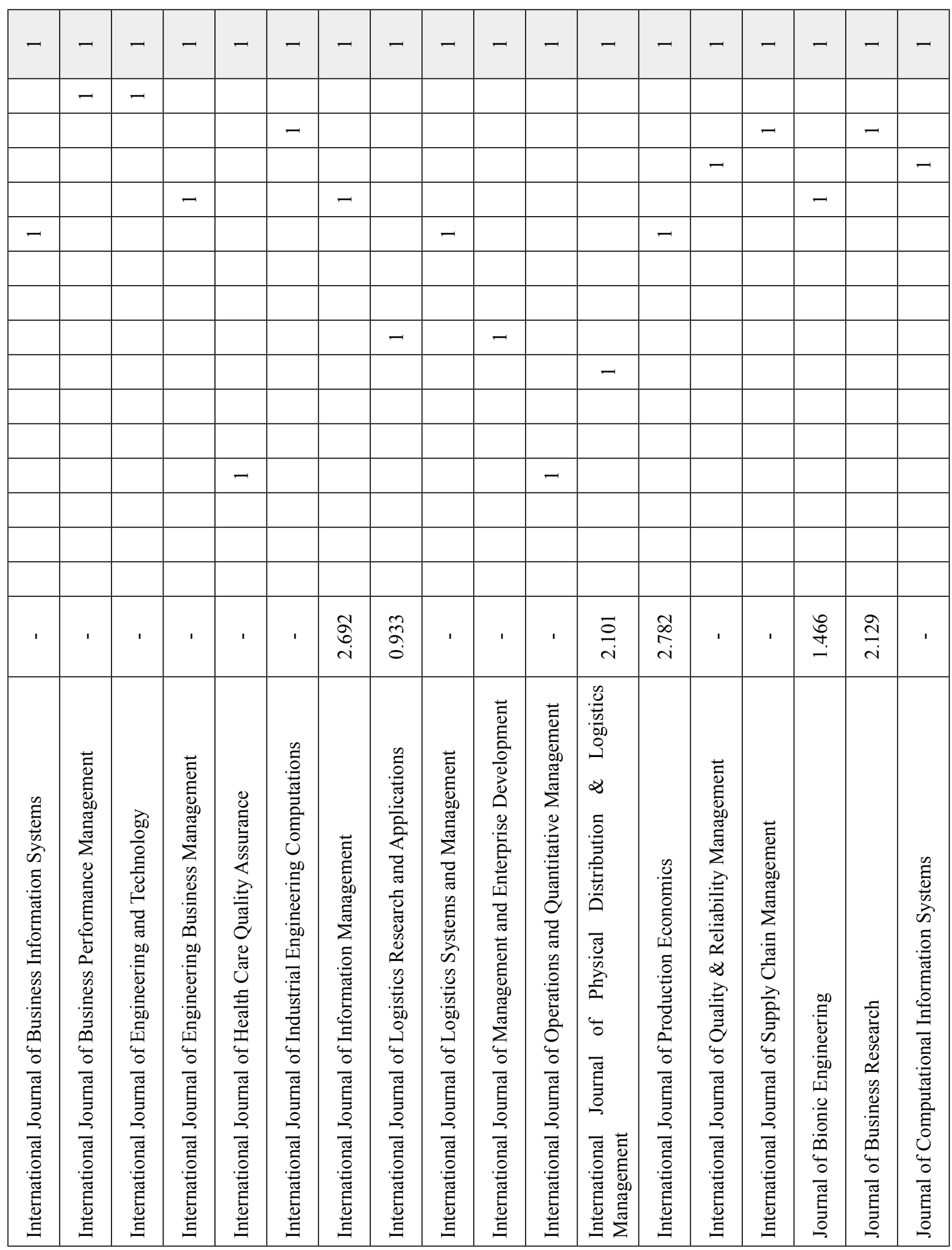




\begin{tabular}{|c|c|c|c|c|c|c|c|c|c|c|c|c|c|c|c|c|}
\hline \multirow[t]{3}{*}{ - } & - & - & - & - & - & - & - & - & - & - & - & - & - & - & - & - \\
\hline & & & & & & - & & & & & - & & & & & - \\
\hline & & & & & - & & & & & & & & & & & \\
\hline \multicolumn{17}{|l|}{-} \\
\hline & & & - & & & & & - & & - & & & & - & & \\
\hline & & - & & - & & & & & & & & - & & & & \\
\hline & & & & & & & & & & & & & & & - & \\
\hline & & & & & & & & & & & & & & & & \\
\hline & & & & & & & & & - & & & & & & & \\
\hline & - & & & & & & & & & & & & & & & \\
\hline & & & & & & & & & & & & & & & & \\
\hline & & & & & & & & & & & & & & & & \\
\hline & & & & & & & & & & & & & & & & \\
\hline & & & & & & & & & & & & & & & & \\
\hline & & & & & & & - & & & & & & - & & & \\
\hline ' & ' & ' & $\begin{array}{l}\stackrel{\mathscr{B}}{\longrightarrow} \\
\stackrel{-}{-}\end{array}$ & $\begin{array}{l}\hat{\circ} \\
\text { aे }\end{array}$ & ' & 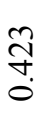 & $\stackrel{\overbrace{}}{\widetilde{N}}$ & ' & $\begin{array}{l}\hat{n} \\
\dot{0} \\
0\end{array}$ & ' & $\begin{array}{l}\text { J } \\
\stackrel{0}{0}\end{array}$ & $\begin{array}{l}\text { రু } \\
\text { مे } \\
\text { r. }\end{array}$ & ণ̃ & 1 & $\begin{array}{l}\stackrel{\infty}{ } \\
\text { ஸे } \\
\text { n. }\end{array}$ & $\begin{array}{l}\underset{T}{ \pm} \\
\stackrel{0}{0} \\
0\end{array}$ \\
\hline 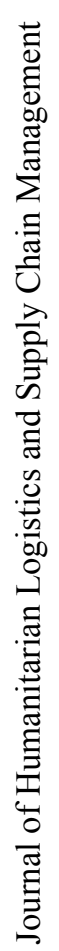 & 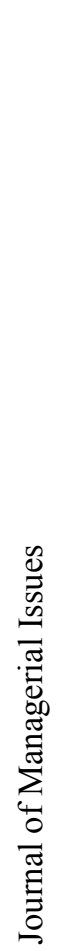 & 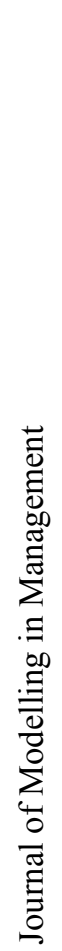 & 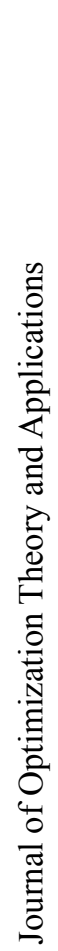 & 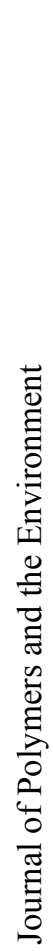 & 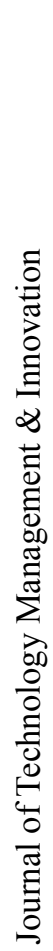 & 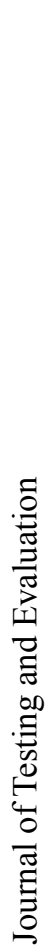 & 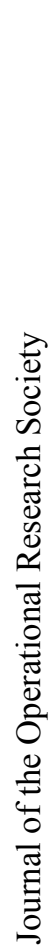 & 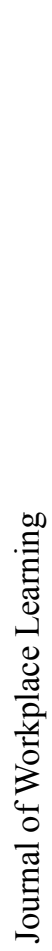 & 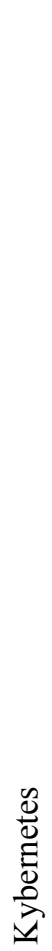 & 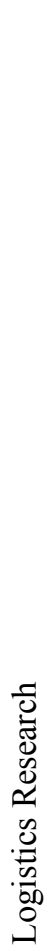 & 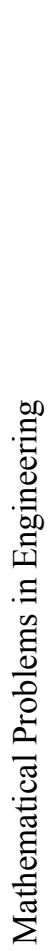 & $\begin{array}{l}\widetilde{0} \\
\stackrel{0}{0} \\
\text { ర్ }\end{array}$ & 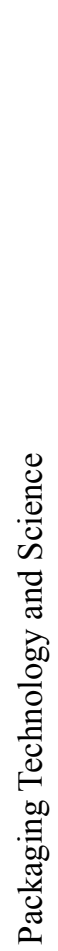 & 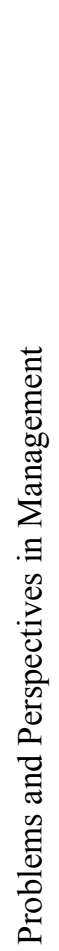 & 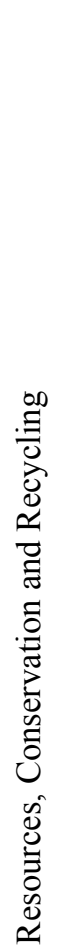 & 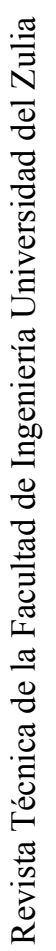 \\
\hline
\end{tabular}




\begin{tabular}{|c|c|c|c|c|c|c|}
\hline- & - & - & - & - & - & 8 \\
\hline & & & & & & $\cong$ \\
\hline & & & & & & $\approx$ \\
\hline & - & & & - & & $\simeq$ \\
\hline- & & & & & & $=$ \\
\hline & & & & & - & $\simeq$ \\
\hline & & - & & & & 6 \\
\hline & & & & & & $\nabla$ \\
\hline & & & - & & & $=$ \\
\hline & & & & & & $m$ \\
\hline & & & & & & $N$ \\
\hline & & & & & & $N$ \\
\hline & & & & & & $\nabla$ \\
\hline & & & & & & - \\
\hline & & & & & & $N$ \\
\hline & & & & & & - \\
\hline 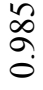 & \begin{tabular}{l}
$\infty$ \\
\multirow{\sigma}{0}{} \\
$i$
\end{tabular} & 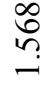 & $\frac{2}{\stackrel{2}{~}}$ & ' & 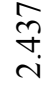 & \\
\hline $\begin{array}{l}\text { Do } \\
. \\
0 \\
0 \\
0 \\
0 \\
0\end{array}$ & 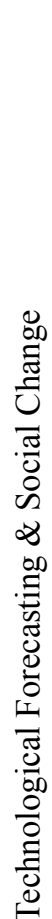 & 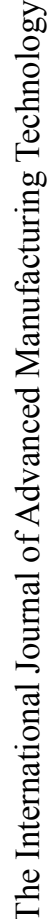 & 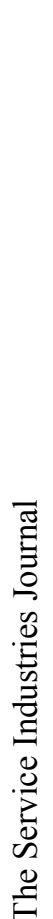 & 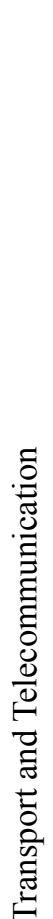 & 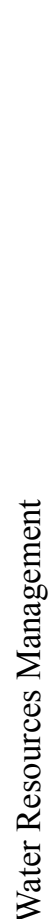 & है \\
\hline
\end{tabular}

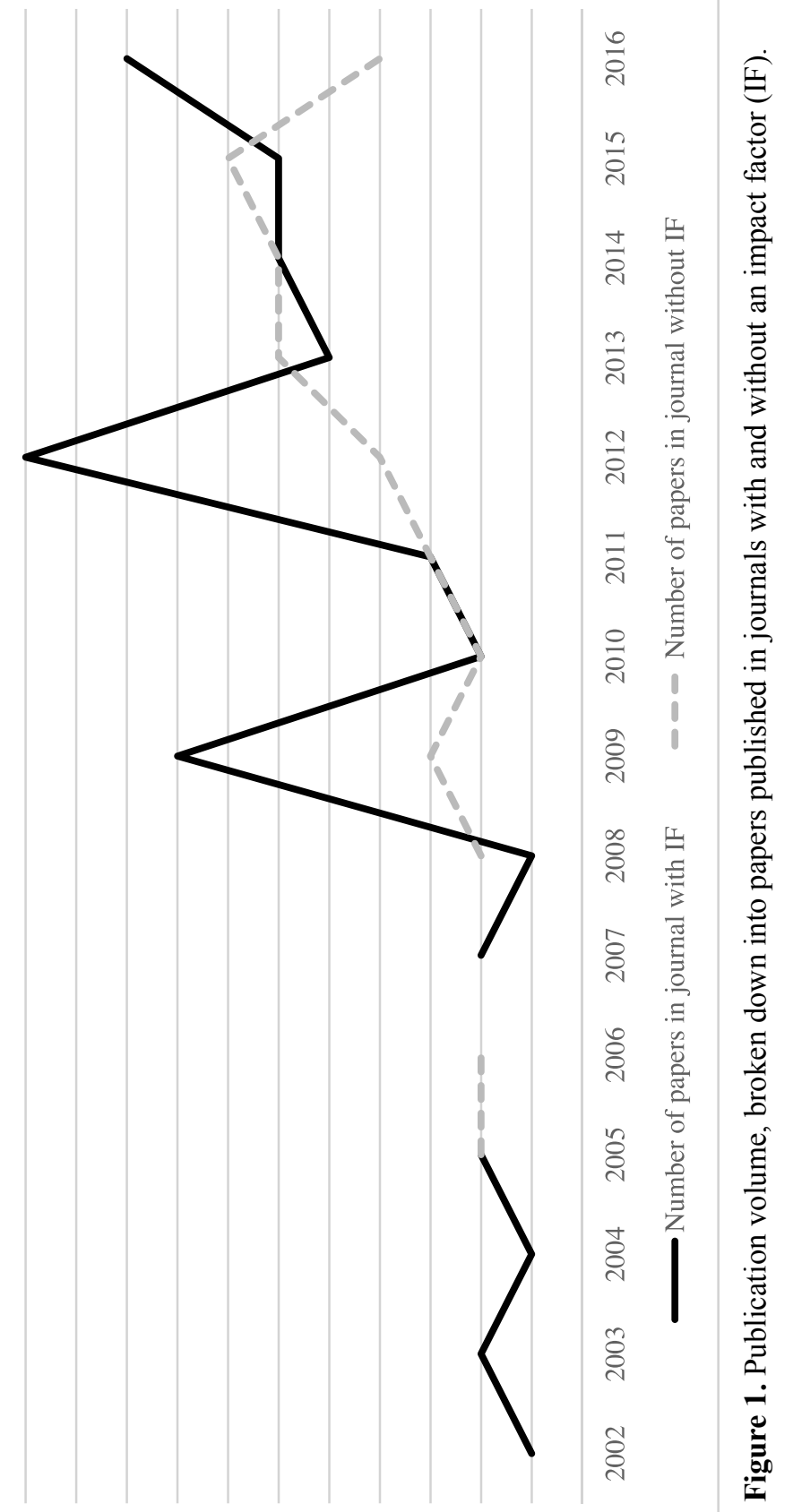




\section{The performance of journals}

Tables 1 and 2 present the IF of the journals where the studies were published. For Hsieh and Chang (2009), the value of publications is usually evaluated by the classification of the journals in Journal Citation Report (JCR). As IF is an influential tool in modern academia, it is used to evaluate the relative importance of a paper. Tables 1 and 2 list IF of journals using information from Thomson Reuters 2015. The IF helps evaluate the journal's relative importance among similar journals. It can be argued that most of the papers have been presented in journals with high IF, considering that of the 100 papers analysed, 61 were published in journals with JCR.

According to Kim and McMillan (2008), although the citation analysis is based on counting citations, this process is much more complex than simple counting. The analysis points to influent centres (Fetscherin and Usunier, 2012) and maps out the connections among papers of a research area (Kim and McMillan, 2008). Therefore, an analysis of citations demonstrates the suitability of the study to other academic researchers in related fields of knowledge (Fetscherin and Heinrich, 2015). As done in Michels and Schmoch (2014), it was assumed that there are no methodologies to judge the quality of the papers published on a large extent. According to Michels and Schmoch (2014), the most common ways to obtain many citations are as follows:

- Submitting a paper to a multidisciplinary journal, considering the number of pages, because these journals and their papers tend to be more frequently cited than smaller ones.

- Submitting the paper to an US-American journal. According to Michel and Schmoch (2014), American journals have a broader readership comparatively to the world average.

- Submitting the paper to journals with high and updated IF, i.e., journals that, independently of their national origin, are very cited.

- Aiming at co-publications with researchers who are very cited, especially, American ones.

Table 2 presents the relation of citations received by each journal of the sample of 100 papers related to the theme. Papers of journals of the sample were considered connected if one of them mentions the other in their references. Tables 1 and 2 showed different results. Production Planning \& Control, Benchmarking, International Journal of Production Research took the first places in the publications and also received many citations, revealing its relevance for the theme development. Although Computers \& Industrial Engineering, European Journal of Information Systems, and Computers in Industry have published few papers, they received many citations.

According to Wohlin (2009), with regard to the w index, the papers having at least 5 citations are seen as successful. For Kosmulski (2013), papers that receive at least 10 citations have a greater impact than papers with 5-9 citations, while papers with at least 20 citations have a greater impact than those with 10-19 citations, and so on (Kosmulski, 2013). Despite their high impact factor, journals as Journal of Cleaner Production, Omega and Ecological Economics were not significantly cited, so they ranked lower in relation to the quantity of publications. This implies that these journals have a good level of relevancy with studies on Balanced Scorecard for performance evaluation of supply chains, but not on their ability to deliver impacts. 


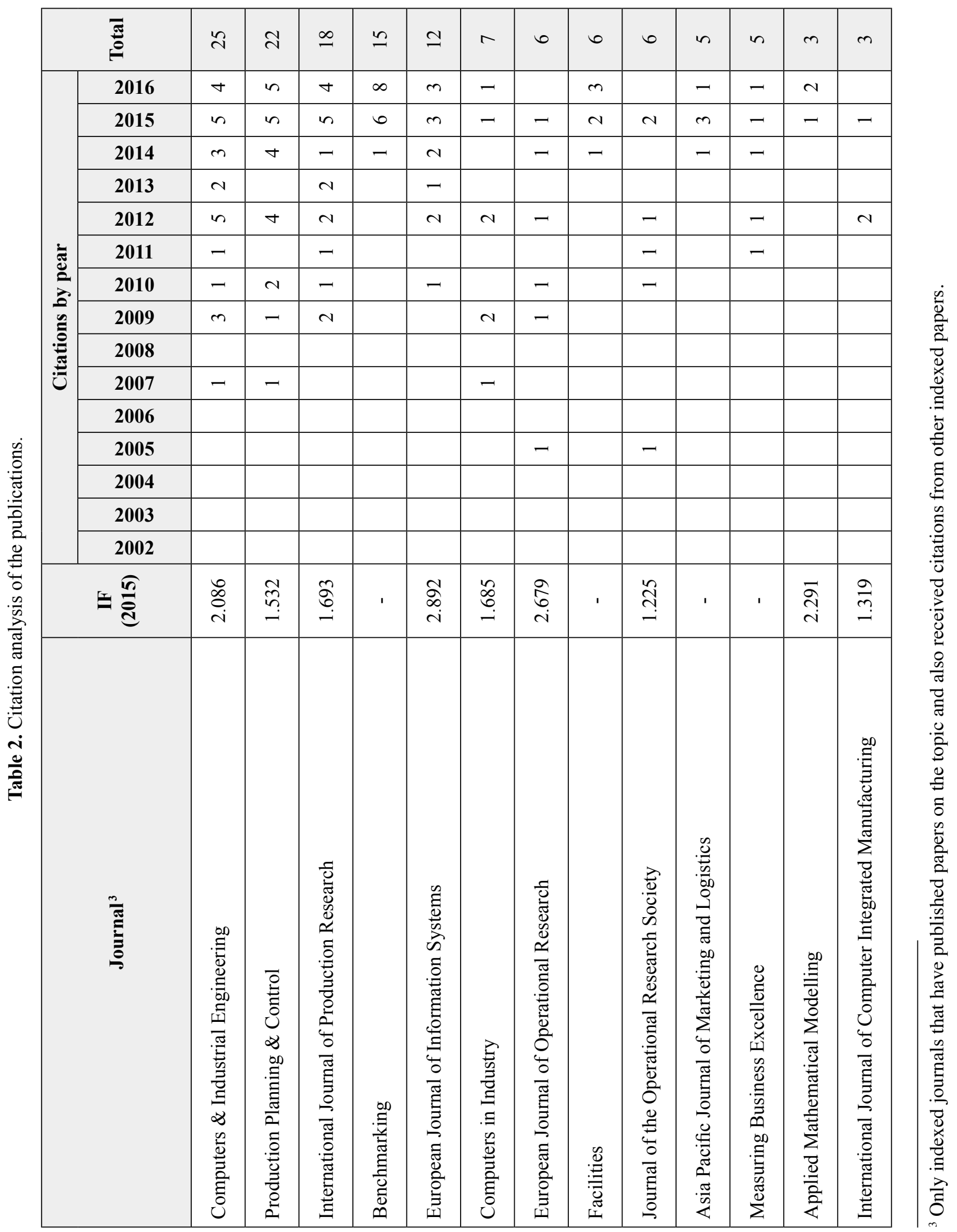




\begin{tabular}{|c|c|c|c|c|c|c|c|c|c|c|}
\hline$m$ & $m$ & $m$ & $m$ & N & - & - & - & - & - & - \\
\hline- & - & $N$ & - & & & & & & - & - \\
\hline \multirow[t]{3}{*}{$N$} & & - & - & & - & & - & & & \\
\hline & - & & & & & & & & & \\
\hline & & & - & $N$ & & - & & - & & \\
\hline & & & & & & & & & & \\
\hline & & & & & & & & & & \\
\hline & - & & & & & & & & & \\
\hline & & & & & & & & & & \\
\hline & & & & & & & & & & \\
\hline & & & & & & & & & & \\
\hline & & & & & & & & & & \\
\hline & & & & & & & & & & \\
\hline & & & & & & & & & & \\
\hline & & & & & & & & & & \\
\hline ' & $\begin{array}{l}\vec{\sigma} \\
\stackrel{i}{i}\end{array}$ & $\underset{\substack{\infty \\
i}}{\stackrel{\infty}{i}}$ & $\frac{0}{2}$ & $\begin{array}{l}\underset{ठ}{0} \\
\text { d }\end{array}$ & $\stackrel{\infty}{\stackrel{\infty}{N}}$ & $\begin{array}{l}\hat{\sigma} \\
\hat{\sigma}\end{array}$ & ' & 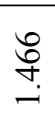 & $\frac{\text { ปิ }}{\text { ป }}$ & 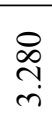 \\
\hline 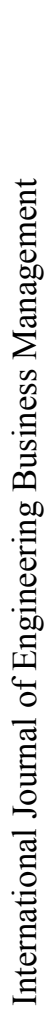 & 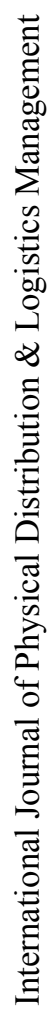 & 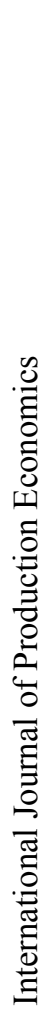 & 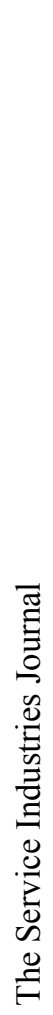 & 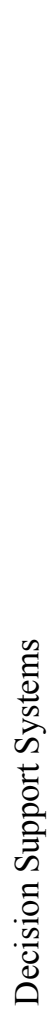 & 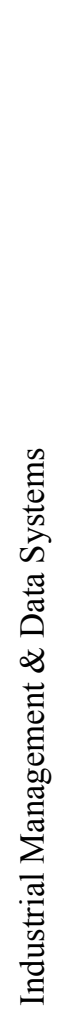 & 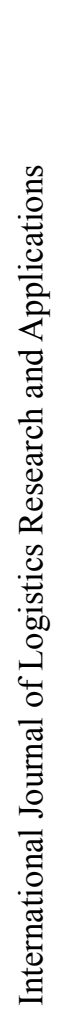 & 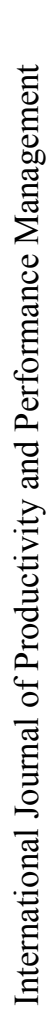 & 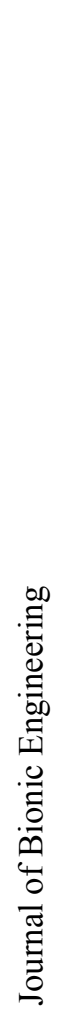 & 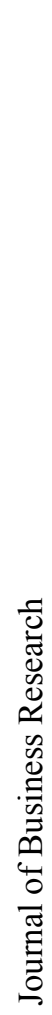 & 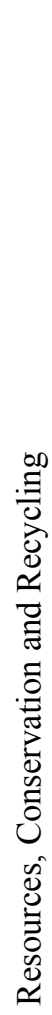 \\
\hline
\end{tabular}




\section{Publications by authors' affiliation country}

The participation of countries may be gauged by analysing the author's affiliations. Table 3 shows the countries with respect to the quantity of published papers and its percentage, the papers of a single country, the number of papers that arose from the first author's country, and the number of internationally collaborated papers.

Table 3. Papers by authors' affiliation country and international collaborations.

\begin{tabular}{|c|c|c|c|c|c|}
\hline Country & $\mathbf{T P}$ & $\mathbf{T P}(\%)$ & SP & FP & $\mathbf{C P}$ \\
\hline India & 14 & 14 & 12 & 1 & 1 \\
\hline UK & 12 & 12 & 5 & & 7 \\
\hline China & 9 & 9 & 8 & 1 & \\
\hline Taiwan & 9 & 9 & 7 & 2 & \\
\hline Italy & 9 & 9 & 7 & 1 & 1 \\
\hline Iran & 9 & 9 & 7 & 1 & 1 \\
\hline Turkey & 5 & 5 & 4 & 1 & \\
\hline Spain & 5 & 5 & 4 & & 1 \\
\hline USA & 5 & 5 & 3 & & 2 \\
\hline Germany & 3 & 3 & 3 & & \\
\hline Greece & 3 & 3 & 3 & & \\
\hline Singapore & 3 & 3 & 2 & & 1 \\
\hline Brazil & 3 & 3 & 1 & 2 & \\
\hline South Korea & 3 & 3 & 1 & 2 & \\
\hline Ireland & 3 & 3 & 1 & 1 & 1 \\
\hline Malaysia & 3 & 3 & 1 & 1 & 1 \\
\hline France & 3 & 3 & 1 & & 2 \\
\hline The Netherlands & 2 & 2 & 2 & & \\
\hline Canada & 2 & 2 & 1 & & 1 \\
\hline New Zealand & 2 & 2 & & 2 & \\
\hline Norway & 2 & 2 & & & 2 \\
\hline Australia & 1 & 1 & 1 & & \\
\hline Chile & 1 & 1 & 1 & & \\
\hline Czech Republic & 1 & 1 & 1 & & \\
\hline
\end{tabular}




\begin{tabular}{|c|c|c|c|c|c|}
\hline Denmark & 1 & 1 & 1 & & \\
\hline Egypt & 1 & 1 & 1 & & \\
\hline Estonia & 1 & 1 & 1 & & \\
\hline Indonesia & 1 & 1 & 1 & & \\
\hline Portugal & 1 & 1 & 1 & & \\
\hline Slovenia & 1 & 1 & 1 & & \\
\hline Sweden & 1 & 1 & & & \\
\hline Colombia & 1 & 1 & & & 1 \\
\hline Thailand & 1 & 1 & & & 1 \\
\hline Philippines & 1 & 1 & & & \\
\hline Saudi Arabia & 1 & 1 & & & \\
\hline
\end{tabular}

TP: total papers; SP: single country papers; FP: papers with first author's country; CP: internationally collaborative papers.

Although investigations on SCM have made various improvements, there is a scarcity of information and academic contributions on the specific characteristics (similarities and dissimilarities) of supply chains that are in place predominantly in developing and emerging countries (Silvestre, 2015). Keeping in mind this gap and considering that bibliometrics has a key role in the analysis of scientific literature, with indicators that show the degree of development of an area of knowledge (Pereira et al., 2015), it is important to know which countries participated in the development of the published papers.

Based on Table 3, it can be stated that studies on BSC for evaluating the performance of supply chains that are in place mainly in developing and emerging countries have obtained great importance. Looking at Table 3, it is interesting to observe that the majority of the papers published were developed by researchers from India, China, Taiwan, Iran, Turkey, Singapore, Brazil, South Korea, Malaysia, New Zealand, Australia, Chile, Czech Republic, Egypt, Estonia, Indonesia, Slovenia, Colombia, Thailand, Philippines, and Saudi Arabia. This result contrasts with Kishida and Matsui (1997) who state that Gross Domestic Product (GDP) is strongly associated with the quantity of works. The finding also contrasts with other study fields of the supply chains literature. Zailani et al. (2015) stated that the majority of the literature on supply chain security practices have been written from the perspective and experience of developed countries (USA, Europe, and Japan), and few studies examining the context of emerging countries were developed. Spiegel et al. (2014) analysed the research field of supply chains integration and checked that 55.92\% of the publications in Web of Science are from USA, Germany, England, Canada, Italy, and France. Taticchi et al. (2015) explored decision-support tools and performance management in the domain of sustainable SCM in the Web of Science database. They checked that $83.94 \%$ of papers about performance management are from USA, United Kingdom, Canada, Germany, Australia, France, Spain, and Italy; and 70\% of papers about decision-support tools are from USA, Germany, United Kingdom, France, Australia, and Denmark.

It is important to state that, among the emerging countries, China has numerous participations in both research fields aforementioned. The observation of Table 3 is quite interesting, as, according to Yang (2014), a large number of products are produced in emerging economies and advanced markets, being significantly important to better understand the mechanisms of improving agility and performance of manufacturers and their supply chains for developed economies. 


\section{Technical procedures used for developing the papers}

Table 4 shows the yearly distribution of papers in relation to the technical procedure used for developing it, classified by Nakano (2012) for the area of operations management (OM). The literature review is based on conceptual discussions on the main published works. The modelling uses mathematical techniques to illustrate how a production system operates fully or partially, while the simulation uses computational techniques to simulate operation. The case study conducts a detailed analysis of one or more objects of study without the active participation of the researcher in the collected results. The survey employs the use of the data collection instrument, making use of sampling and analysis techniques and statistical inference. Action research involves the production of knowledge-oriented practice, with the modification of a given reality that is part of the research process. Experimental research studies the causal association between two variables of a system under conditions controlled by the researcher.

Table 4. Classification and yearly distribution of papers in relation to the technical procedure that researchers used to develop it.

\begin{tabular}{|c|c|c|c|c|c|c|c|c|c|c|c|c|c|c|c|c|}
\hline \multirow[b]{2}{*}{ Technical procedure } & \multicolumn{15}{|c|}{ Year } & \multirow[b]{2}{*}{ Total } \\
\hline & ֻั & હ) & ষ্ণ & ஜे & ஓ̊ั & હे & $\stackrel{\infty}{\stackrel{\overbrace{}}{ి}}$ & ڤ્సે & 를 & $\overline{\bar{\nu}}$ & 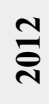 & $\stackrel{m}{\stackrel{\text { }}{二}}$ & 를 & 䎹 & 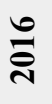 & \\
\hline Case study & & 1 & 1 & 2 & & 1 & & 6 & 2 & 2 & 3 & 4 & 5 & 5 & 5 & 37 \\
\hline Survey & & 1 & & & 1 & 1 & 2 & 1 & & & 4 & 2 & 2 & 5 & 4 & 23 \\
\hline Literature review & 1 & & & 1 & & 1 & 1 & 2 & 2 & 1 & 1 & 3 & 2 & & 1 & 16 \\
\hline Modelling & & & & & & & & 2 & & 2 & 4 & 2 & 2 & 2 & 2 & 16 \\
\hline Experiment & & & & 1 & & & & & & & 1 & & 1 & & 1 & 4 \\
\hline Simulation & & & & & & & & & & 1 & 2 & & & 1 & & 4 \\
\hline Action research & & & & & & & & & & & & & & & & 0 \\
\hline
\end{tabular}

Looking at Table 4, it can be observed that the case study showed the highest incidence (37\%), followed by the survey (23\%), literature review and modelling (16\%), and simulation and experiment (4\%). Although the literature review is essential for developing any academic paper, in this study only the papers that adopted the conceptual approach in its development were classified as theoretical papers.

According to the classification proposed by Turrioni and Melo (2012), apparently, it is possible to state that the qualitative research (case study, literature review, and action research) has a certain predominance in the approach used for the development of papers, as $53 \%$ of the papers used methods nominally linked to this approach. However, it is important to state that the quantitative approach was more used, as, in addition to methods traditionally linked to it (modelling, survey, simulation, and experiment), most of the case studies have increased use of quantitative techniques. Case studies have used for diminishing the subjective character of the analysis and validating the modifications made in already established methods and new techniques and tools developed as Fuzzy logic, Supply Chain Operations Reference (SCOR) model, Analytic Hierarchy Process (AHP), Analytic Network Process (ANP), among others.

This result corroborates the statements of Callado and Jack (2015), which state that use the BSC to evaluate supply chain performance has some limitations, such as approach top-down, the absence of a formal methodology for implementation, and subjectivity of the selection of metrics. The increasing use of quantitative techniques suggests that improvement gaps identified in various papers developed on the topic are being properly exploited (Agami et al., 2012; De Felice et al., 2015; Lin et al., 2014; Naini et al., 2011; Piotrowicz and Cuthbertson, 2015; Shafiee et al., 2014; Sharma and Bhagwat, 2007). 


\section{CONCLUSIONS}

This paper brings advances for the literature of OM presenting a study that encompasses bibliometric analysis of the academic production on BSC for performance evaluation of supply chains and represents a starting point for researchers who want to improve the theme.

The bibliometric study revealed that although some oscillations have occurred, studies approaching the use of BSC for evaluating supply chains performance increased (keeping in mind that in 2002, researchers published only one paper). In 2012, the highest number of papers published increased to 15 , and $49 \%$ of the publications occurred in the last four years.

As for the technical procedure used in the researches, it can be stated that the focus of the papers has matured, moving from a predominantly conceptual emphasis to real applications based on case studies, survey, and simulation. The predominance of the case study in the investigations reinforces the results of Barratt et al. (2011), Berto and Nakano (2000), Dooley (2016), Gattiker and Parente (2007), Miguel (2007), Pedraza-Acosta et al. (2016), and Walter and Tubino (2013), who state that this is the most used technical procedure in researches of industrial engineering and OM. In addition, taking into consideration the recent development of theme, this result reinforce Voss et al. (2002), who state that this methodological procedure is quite suitable for analyses of processes, in which experience is rare and context conditions are unknown, and Runfola et al. (2017), who state that certain specific managerial processes are very difficult of investigating using other methods.

The absence of the action research in the literature of performance evaluation of supply chains based on BSC corroborates the results of Avella and Alfaro (2014), who state that its use in literature of OM is not very extensive. Future papers may explore this technical procedure; as for Coughlan and Coghlan (2002), the action research is relevant for the field of $\mathrm{OM}$ because it can solve business problems and make relevant contributions to the theory.

Regarding the methodological approach, the predominance and growing increase of quantitative approach in the investigations reveal that several gaps raised by authors to improve the performance evaluation have been explored. So, the evaluation is becoming more effective and less subjective.

Researches about the theme are very relevant for the advance of science, as most of the publications are concentrated in journals that have an impact factor in Thomson Reuters. The fact that a journal is prestigious can persuade authors to cite that journal without reading the paper or analysing critically its content. Considering the citations index measures only the quantity, it can disregard the actual quality of the paper. Systematic literature review and bibliometrics, as the present paper, help analyse if the papers are really relevant.

From the analysis of author's affiliation country, it was observed that the results presented the contrast with other fields of supply chain management, bearing in mind that the studies on the theme are predominantly from emerging economies. This represents a new trend in the literature of SCM.

\section{Limitations and research opportunities}

It is important to highlight that the methodology used for developing this paper presents some limitations. Firstly, the sample of papers considered was extracted from only two databases, which may have disregarded relevant papers. Possibly a great number of papers about the theme were published in non-indexed journals; this means they are unavailable in the most used databases (SCOPUS and Web of Science). Secondly, despite only papers published in journals due to their greater relevance and quality, papers published in conferences can have important contributions to the development of the theme. Thirdly, the bibliometric study developed in this paper was based on the perceptions of authors, which may disregard aspects considered important from other points of view.

The development of this study was not intended to conclude the topics raised here. The focus of the paper was on the general characterisation of academic production on the theme. Additional future papers in this movement would detect various other contributions and possible shift core research fields. For further investigations, researchers could consider comparing the information and results obtained from other databases with those of this paper. 


\section{REFERENCES}

Agami, N., Saleh, M. \& Rasmy, M. 2012. A hybrid dynamic framework for supply chain performance improvement. IEEE Systems Journal, 6(3): 469-478.

Avella, L. \& Alfaro, J.A. 2014. Spanish University Business Chairs used to increase the deployment of Action Research in Operations Management: a case study and analysis. Action Research, 12(2): 194-208.

Barratt, M., Choi, T.Y. \& Li, M. 2011. Qualitative case studies in operations management: Trends, research outcomes, and future research implications. Journal of Operations Management, 29(4): 329-342.

Baumgartner, H. \& Pieters, R. 2003. The structural influence of marketing journals: a citation analysis of the discipline and its subareas over time. Journal of Marketing, 67(2): 123-139.

Berto, R. M. V. S. \& Nakano, D. N. 2000. A produção científica nos anais do Encontro Nacional de Engenharia de Produção: um levantamento de métodos e tipos de pesquisa. Produção, 9(2): 65-76.

Blank, L., Vasl, A., Levy, S., Grant, G., Kadas, G., Dafni, A. \& Blaustein, L. 2013. Directions in green roof research: a bibliometric study. Building and Environment, 66: 23-28.

Bornmann, L. \& Marx, W. 2015. Methods for the generation of normalized citation impact scores in bibliometrics: which method best reflects the judgements of experts? Journal of Informetrics, 9(2): 408-418.

Brewer, P.C. \& Speh, T.W. 2000. Using the Balanced Scorecard to measure supply chain performance. Journal of Business Logistics, 21(1): 75-93.

Bronzo, M., Resende, P.T.V., Oliveira, M.P.V., McCormack, K.P., Sousa, P.R. \& Ferreira, R.L. 2013. Improving performance aligning business analytics with process orientation. International Journal of Information Management, 33(2): 300-307.

Brun, A., Salama, K.F. \& Gerosa, M. 2009. Selecting performance measurement systems: matching a supply chain's requirements. European Journal of Industrial Engineering, 3(3): 336-362.

Callado, A.A.C. \& Jack, L. 2015. Balanced scorecard metrics and specific supply chain roles. International Journal of Productivity and Performance Management, 64(2): 288-300.

Carnevalli, J.A. \& Miguel, P.A.C. 2008. Review, analysis and classification of the literature on QFD - types of research, difficulties and benefits. International Journal of Production Economics, 114(2): 737-754.

Chang, H.H. 2009. An empirical study of evaluating supply chain management integration using the balanced scorecard in Taiwan. The Service Industrial Journal, 29(2): 185-202.

Chang, H.H., Hung, C.J., Wong, K.H. \& Lee, C.H. 2013. Using the balanced scorecard on supply chain integration performance - a case study of service businesses. Service Business, 7(4): 539-561.

Charvet, F.F., Cooper, M.C. \& Gardner, J.T. 2008. The intellectual structure of supply chain management: a bibliometric approach. Journal of Business Logistics, 29(1): 47-73.

Coughlan, P. \& Coghlan, D. 2002. Action research for operations management. International Journal of Operations \& Production Management, 22(2): 220-240.

Dath, T.N.S., Rajendran, C. \& Narashiman, K. 2010. An empirical study on supply chain management in India: the perspective of original equipment manufacturers and suppliers. European Journal of Industrial Engineering, 4(1): 2-39.

De Felice, F., Petrillo, A. \& Autorino, C. 2015. Development of a framework for sustainable outsourcing: Analytic Balanced Scorecard Method (A-BSC). Sustainability, 7(7): 8399-8419.

Dooley, K.J. 2016. Using manifest content analysis in purchasing and supply management research. Journal of Purchasing \& Supply Management, 22(4): 244-246.

Du, H., Li, B., Brown, M.A., Mao, G., Rameezdeen, R. \& Chen, H. 2015. Expanding and shifting trends in carbon market research: a quantitative bibliometric study. Journal of Cleaner Production, 103: 104-111.

Eskafi, S.H., Roghanian, E. \& Jafari-Eskandari, M. 2015. Designing a performance measurement system for supply chain using balanced scorecard, path analysis, cooperative game theory and evolutionary game theory: a case study. International Journal of Industrial Engineering Computations, 6(2): 157-172. 
Estampe, D., Lamouri, S., Paris, J.L. \& Brahim-Djelloul, S. 2013. A framework for analysing supply chain performance evaluation models. International Journal of Production Economics, 142(2): 247-258.

Fahimnia, B., Sarkis, J. \& Davarzani, H. 2015. Green supply chain management: a review and bibliometric analysis. International Journal of Production Economics, 162: 101-114.

Ferreira, M. 2011. A bibliometric study on Ghoshal's managing across borders. Multinational Business Review, 19(4): 357-375.

Fetscherin, M. \& Heinrich, D. 2015. Consumer brand relationships research: a bibliometric citation meta-analysis. Journal of Business Research, 68(2): 380-390.

Fetscherin, M. \& Usunier, J.C. 2012. Corporate branding: an interdisciplinary literature review. European Journal of Marketing, 46(5): 733-753.

Fetscherin, M., Voss, H. \& Gugler, P. 2010. 30 years of foreign direct investment to China: an interdisciplinary literature review. International Business Review, 19(3): 235-246.

Gattiker, T.F. \& Parente, D.H. 2007. Introduction to the special issue on innovative data sources for empirically building and validating theories in Operations Management. Journal of Operations Management, 25(5): 957-961.

Hsieh, P.N. \& Chang, P.L. 2009. An assessment of world-wide research productivity in production and operations management. International Journal of Production Economics, 120(2): 540-551.

Kaplan, R.S. \& Norton, D.P. 1996. Using the balanced scorecard as a strategic management system. Harvard Business Review, 74(1): 75-85.

Kim, J. \& McMillan, S.J. 2008. Evaluation of internet advertising research: a bibliometric analysis of citations from key sources. Journal of Advertising, 37(1): 99-112.

Kishida, K. \& Matsui, S. 1997. International publication patterns in social sciences: a quantitative analysis of the IBSS file. Scientometrics, 40(2): 277-298.

Kosmulski, M. 2013. Family-tree of bibliometric indices. Journal of Informetrics, 7(2): 313-317.

Li, S., Ragu-Nathan, B., Ragu-Nathan, T.S. \& Rao, S.S. 2006. The impact of supply chain management practices on competitive advantage and organizational performance. Omega, 34(2): 107-124.

Lin, Y., Tseng, M.L., Chiu, A.S.F. \& Wang, R. 2014. Implementation and performance evaluation of a firm's Green Supply Chain Management under uncertainty. Industrial Engineering and Management Systems, 13(1): 15-28.

Michels, C. \& Schmoch, U. 2014. Impact of bibliometric studies on the publication behaviour of authors. Scientometrics, 98(1): 369-385.

Miguel, P.A.C. 2007. Estudo de caso na engenharia de produção: estruturação e recomendações para sua condução. Produção, 17(1): 216-229.

Naini, S.G.J., Aliahmadi, A.R. \& Jafari-Eskandari, M. 2011. Designing a mixed performance measurement system for environmental supply chain management using evolutionary game theory and balanced scorecard: a case study of an auto industry supply chain. Resources, Conservation and Recycling, 55(6): 593-603.

Nakano, D. 2012. Métodos de pesquisa adotados na engenharia de produção e gestão de operações. In: Miguel, P. A. C. (Org.). Metodologia de pesquisa em engenharia de produção e gestão de operações. Pp 65-74. 2nd ed. Elsevier/ABEPRO, Rio de Janeiro.

Ngai, E.W.T., Moon, K.K.L., Riggins, F.J. \& Yi, C.Y. 2008. RFID research: an academic literature review (1995-2005) and future research directions. International Journal of Production Economics, 112(1): 510-520.

Park, J.H., Lee, J.K. \& Yoo, J.S. 2005. A framework for designing the balanced supply chain scorecard. European Journal of Information Systems, 14(4): 335-346.

Pedraza-Acosta, I., Pilkington, A. \& Barnes, D. 2016. Production systems and supplier selection: a multi-phase process model. Production Planning \& Control, 27(9): 717-726.

Pereira, T.F., Miranda, R.C. \& Montevechi, J.A.B. 2015. Gestão do conhecimento em projetos de simulação: um estudo bibliométrico. Perspectivas em Ciência da Informação, 20(1): 138-155. 
Phelan, S.E., Ferreira, M. \& Salvador, R. 2002. The first twenty years of the Strategic Management Journal. Strategic Management Journal, 23(12): 1161-1168.

Piotrowicz, W. \& Cuthbertson, R. 2015. Performance measurement and metrics in supply chains: an exploratory study. International Journal of Productivity and Performance Management, 64(8): 1068-1091.

Podsakoff, P., MacKenzie, S., Podsakoff, N. \& Bacharach, D. 2008. Scholarly influence in the field of management: a bibliometric analysis of the determinants of university and author impact in the management literature in the past quarter century. Journal of Management, 34(4): 641-720.

Rajesh, R., Pugazhendhi, S., Ganesh, K., Ducq, Y. \& Koh, S.C.L. 2012. Generic balanced scorecard framework for third party logistics service provider. International Journal of Production Economics, 140(1): 269-282.

Ramos-Rodriguez, A. \& Ruiz-Navarro, J. 2004. Changes in the intellectual structure of strategic management research: a bibliometric study of the Strategic Management Journal, 1980-2000. Strategic Management Journal, 25(10): 981-1004.

Romo-Fernández, L.M., López-Pujalte, C., Bote, V.P.G. \& Moya-Anegón, F. 2011. Analysis of Europe's scientific production on renewable energies. Renewable Energy, 36(9): 2529-2537.

Runfola, A., Perna, A., Baraldi, E. \& Gregori, G.L. 2017. The use of qualitative case studies in top business and management journals: a quantitative analysis of recent patterns. European Management Journal, 35(1): 116-127.

Shafiee, M., Lotfi, F.H. \& Saleh, H. 2014. Supply chain performance evaluation with data envelopment analysis and balanced scorecard approach. Applied Mathematical Modelling, 38(21/22): 5092-5112.

Shafique, M. 2013. Thinking inside the box? Intellectual structure of the knowledge base of innovation research (1988-2008). Strategic Management Journal, 34(1): 62-93.

Sharma, M.K. \& Bhagwat, R. 2007. An integrated BSC-AHP approach for supply chain management evaluation. Measuring Business Excellence, 11(3): 57-68.

Shiau, W.L., Dwivedi, Y.K. \& Tsai, C.H. 2015. Supply chain management: exploring the intellectual structure. Scientometrics, 105(1): 215-230.

Silvestre, B.S. 2015. Sustainable supply chain management in emerging economies: environmental turbulence, institutional voids and sustainability trajectories. International Journal of Production Economics, 167: 156-169.

Spiegel, T., Vasconcelos, P.E.M., Porto, D.L. \& Caulliraux, H.M. 2014. Supply chain integration researches: an overview of the field. International Journal of Supply Chain Management, 3(1): 12-20.

Taticchi, P., Garengo, P., Nudurupati, S.S., Tonelli, F. \& Pasqualino, R. 2015. A review of decision-support tools and performance measurement and sustainable supply chain management. International Journal of Production Research, 53(21): 6473-6494.

Tsang, A.H.C., Jardine, A.K.S. \& Kolodny, H. 1999. Measuring maintenance performance: a holistic approach. International Journal of Operations \& Production Management, 19(7): 691-715.

Turrioni, J.B. \& Mello, C.H.P. 2012. Metodologia de pesquisa em engenharia de produção: estratégias, métodos e técnicas para condução de pesquisas quantitativas e qualitativas. Universidade Federal de Itajubá, Itajubá.

von Krogh, G., Rossi-Lamastra, C. \& Haefliger, S. 2012. Phenomenon-based research in management and organization science: when is it rigorous and does it matter? Long Range Planning, 45(4): 277-298.

Voss, C., Tsikriktsis, N. \& Frohlich, M. 2002. Case research in operations management. International Journal of Operations \& Production Management, 22(2): 195-219.

Walter, O.M.F.C. \& Tubino, D.F. 2013. Métodos de avaliação da implantação da manufatura enxuta: uma revisão da literatura e classificação. Gestão \& Produção, 20(1): 23-45.

Willett, P. 2007. A bibliometric analysis of the Journal of Molecular Graphics and Modelling. Journal of Molecular Graphics and Modelling, 26(3): 602-606.

Wohlin, C. 2009. A new index for the citation curve of researchers. Scientometrics, 81(2): 512-533.

Wu, I.L. \& Chang, C.H. 2012. Using the balanced scorecard in assessing the performance of e-SCM diffusion: a multi-stage perspective. Decision Support Systems, 52(2): 474-485. 
Xu, J., Li, B. \& Wu, D. 2009. Rough data envelopment analysis and its application to supply chain performance evaluation. International Journal of Production Economics, 122(2): 628-638.

Yang, J. 2014. Supply chain agility: securing performance for Chinese manufacturers. International Journal of Production Economics, 150: 104-113.

Zailani, S.H., Subaramaniam, K.S., Iranmanesh, M. \& Shaharudin, M.R. 2015. The impact of supply chain security practices on security operational performance among logistics service providers in an emerging economy: security culture as moderator. International Journal of Physical Distribution \& Logistics Management, 45(7): 652-673.

Zimmermann, K. \& Seuring, S. 2009. Two case studies on developing, implementing and evaluating a balanced scorecard in distribution channel dyads. International Journal of Logistics Research and Applications, 12(1): 63-81.

Submitted: 18/04/2017

Revised: $\quad 01 / 05 / 2019$

Accepted: 18/06/2019 


\section{بطاقة الأداء المتوازن لتقييم أداء سلاسل الإمداد: دراسة ببليومترية}

تاليس بوتيلو دي سوزا، إيزوتيليا كوستا ميلو، بيدرو هنريك دي أوليفيرا، كايو مارسيلو لورينكو، فابيو مولر غيريني

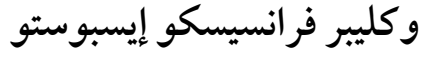

قسم الهندسة الصناعية، كلية ساو كارلوس للهندسة، جامعة ساو باولو، البرازيل

\section{الخاصلاصة}

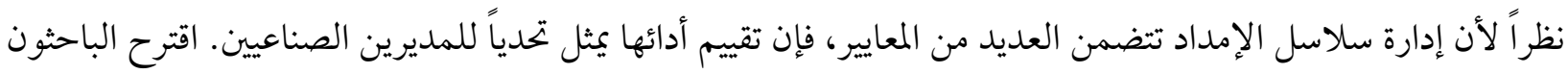

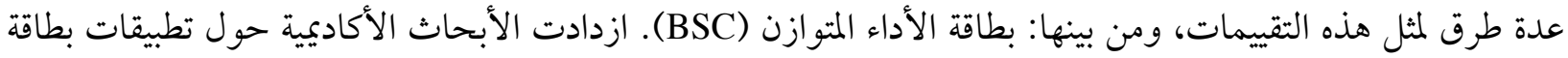

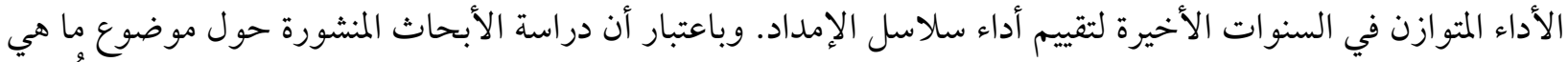

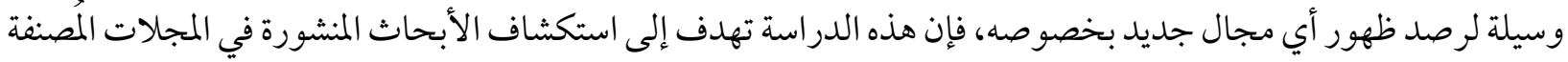
و و SCOPUS)

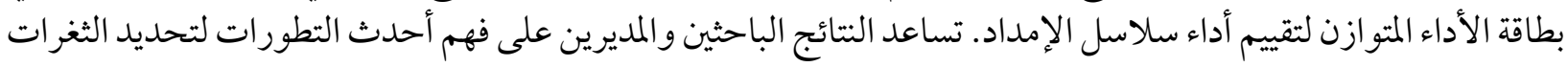

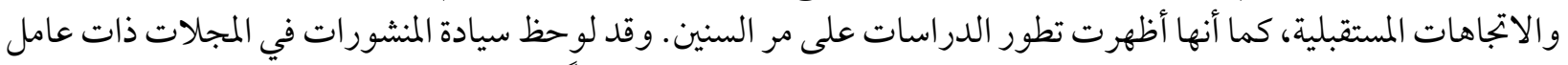

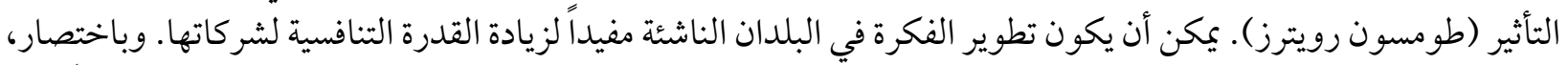

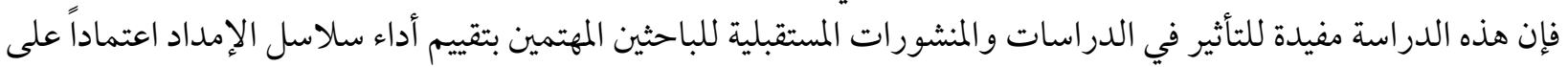

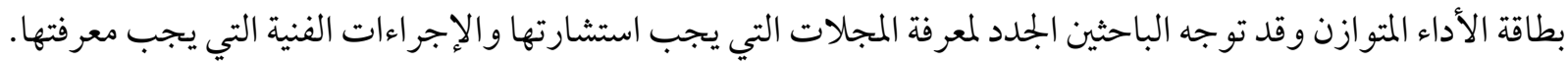

